\title{
ERRATUM
}

\section{Reliability assessment of the Biffl Scale for blunt traumatic cerebrovascular injury as detected on computer tomography angiography}

TO THE READERSHIP: An error appeared in the article by Foreman et al. (Foreman PM, Griessenauer CJ, Kicielinski KP, et al: Reliability assessment of the Biffl Scale for blunt traumatic cerebrovascular injury as detected on computer tomography angiography. J Neurosurg 127:32-35, 2017).

The slice thicknesses of the CTA images in the Methods section were incorrect. The correct measurements appear in the updated sentence shown below.

The images included axial, coronal, and sagittal slices of $0.7-2.5 \mathrm{~mm}, 0.3-2.5 \mathrm{~mm}$, and $0.4-2.5$ $\mathrm{mm}$, respectively.

The article has been corrected online as of July 7, 2017.

Paul M. Foreman, MD

University of Alabama at Birmingham, AL

\section{INCLUDE WHEN CITING}

Published online July 7, 2017; DOI: 10.3171/2017.3.JNS16849a.

CAANS, 2017 